\title{
Interactions between glycopyrronium and indacaterol on cholinergic neurotransmission and contractile response in bovine trachealis
}

\author{
Michele Baroffio $^{1^{*}}$ (D), Giovanni Barisione ${ }^{2}$ and Vito Brusasco ${ }^{1}$
}

\begin{abstract}
Background: Muscarinic-receptor antagonists and $\beta$-adrenoceptor agonists are used, alone or in combination, as first-line treatment for chronic obstructive pulmonary disease. Both drugs decrease airway smooth muscle tone by post-junctional mechanisms but they may have opposing effects on pre-junctional acetylcholine (ACh)-release.

Methods: We studied the effects of the muscarinic-receptor antagonist glycopyrronium (GLY), the $\beta$-adrenoceptor agonist indacaterol (IND) and their combination on electrically-induced ACh-release and contractile response in isolated bovine trachealis. Data were analyzed by paired t-test and analysis of variance for repeated or independent measures with Newmann-Keuls post-hoc test when appropriate.

Results: GLY $10^{-8} \mathrm{M}$ decreased contractile response by $19 \pm 6 \%(p=0.010)$ without altering ACh-release. GLY $10^{-7} \mathrm{M}$ and $10^{-6} \mathrm{M}$ almost abolished contractile responses even if the ACh-release was increased by $27 \pm 19 \%(p<0.001)$ and $20 \pm 8 \%(p=0.004)$, respectively. IND $10^{-7} \mathrm{M}$ had no significant effects on contractile response and ACh-release, whereas IND $10^{-6} \mathrm{M}$ reduced contractile response by $24 \pm 12 \%(p=0.002)$ without altering ACh-release. IND $10^{-5} \mathrm{M}$ decreased contractile response by $51 \pm 17 \%(p<0.001)$ and ACh-release by $22 \pm 11 \%(p=0.004)$. Co-incubation with GLY $10^{-8} \mathrm{M}$ and IND $10^{-7} \mathrm{M}$ did not alter ACh-release but inhibited contractile response by $41 \pm 8 \%$ $(p<0.001)$. The latter effect was greater than with GLY $10^{-8} \mathrm{M}$, or IND $10^{-7} \mathrm{M}$, or IND $10^{-6} \mathrm{M}$ given separately $\left(p<0.001\right.$ for all). The increment of ACh-release caused by GLY was attenuated by IND $10^{-5} \mathrm{M}$, though this did not affect contractile response.

Conclusions: At equimolar concentration, GLY alone attenuates airway smooth muscle contraction more than IND, despite an increased ACh-release. Combination of GLY with IND at submaximal concentrations has more than additive effect suggesting a synergistic post-junctional effect. Adding GLY to IND provides a greater inhibitory effect on airway smooth muscle contraction than increasing IND concentration.
\end{abstract}

Keywords: Airway smooth muscle, Acetylcholine, Long-acting muscarinic antagonist, Long-acting $\beta$-adrenoceptor agonist

\footnotetext{
* Correspondence: michele.baroffio@unige.it

${ }^{1}$ Dipartimento di Medicina Interna e Specialità Mediche, Università di

Genova, Viale Benedetto XV 6, 16132 Genoa, Italy

Full list of author information is available at the end of the article
}

\section{Ciomed Central}

(c) The Author(s). 2017 Open Access This article is distributed under the terms of the Creative Commons Attribution 4.0 International License (http://creativecommons.org/licenses/by/4.0/), which permits unrestricted use, distribution, and reproduction in any medium, provided you give appropriate credit to the original author(s) and the source, provide a link to the Creative Commons license, and indicate if changes were made. The Creative Commons Public Domain Dedication waiver (http://creativecommons.org/publicdomain/zero/1.0/) applies to the data made available in this article, unless otherwise stated. 


\section{Background}

In airway smooth muscle, the acetylcholine (ACh)-release and the contractile response are thought to be modulated both by cholinergic muscarinic (M) receptors [1-7] and $\beta_{2}$-adrenoceptors $[8,9]$. Physiologically, the airway smooth muscle contractile response is enhanced by ACh acting on post-junctional $\mathrm{M}_{3}$ receptors and inhibited by catecholamine acting on postjunctional $\beta_{2}$-adrenoceptors. Therefore, M-receptor antagonists and $\beta_{2}$-adrenoceptor agonists are used alone or in combination for treatment of chronic obstructive pulmonary disease (COPD). However, their effects at pre-junctional level are opposing, with muscarinicreceptor antagonists increasing [1-7] and $\beta_{2}$-adrenoceptor agonists decreasing ACh-release [8,9] from post-ganglionic nerves.

The relaxing effect of $\mathrm{M}$-antagonists on airway smooth muscle might be partially offset by stimulation of prejunctional $\mathrm{M}_{2}$ or $\mathrm{M}_{4}$ auto-receptors $[3,5,6]$ resulting in an increase of ACh-release. By contrast, $\beta_{2}$-adrenoceptor agonists significantly inhibit ACh-release, thus enhancing their post-junctional relaxing effects [8]. Therefore, one can speculate that the inhibitory pre-junctional effect of $\beta_{2}$-adrenoceptor agonists on ACh-release may counteract the stimulatory pre-junctional effect of $M$ receptor antagonists by functional antagonism.

On the other hand, the relaxing effect of $\beta_{2}$-adrenoceptor agonists may be partially offset by stimulation of post-junctional $\mathrm{M}_{2}$-receptors, via the receptor-coupled $\mathrm{G}_{\mathrm{i}}$-protein inhibiting adenylyl-cyclase [10]. Therefore, non-selective $\mathrm{M}$-receptor antagonists may enhance the effect of $\beta_{2}$-adrenoceptor agonists by a synergistic effect at post-junctional level, as suggested by data in airway [11] and ocular [12] smooth muscle. Were this the case, then it may represent a rationale for clinical use of combined $\beta_{2}$-adrenoceptor agonists and muscarinic antagonists at doses lower than those of the individual components used alone.

The aims of this study in vitro were to 1) compare the inhibitory effects of two long-acting bronchodilators, the $\mathrm{M}$-antagonist glycopyrronium (GLY) and the $\beta_{2}$-adrenoceptor agonist indacaterol (IND) on airway smooth muscle contraction in isolated bovine trachealis, 2) evaluate the pre-junctional effects of GLY and IND on ACh-release, and 3) investigate whether GLY and IND have additive or synergistic effects on ACh-release and contractile response.

\section{Methods}

\section{Tissue preparation}

Fifty bovine tracheas were obtained from two local abattoirs. The ethical approval was not required as we were not involved in the care or killing of the animals. After death the tracheas were removed and immersed in chilled $\left(4^{\circ} \mathrm{C}\right)$ physiologic salt solution (PSS) of the following composition $\left(\mathrm{MgSO}_{4} 0.8 \mathrm{mM}, \mathrm{KH}_{2} \mathrm{PO}_{4} 1.2 \mathrm{mM}\right.$, $\mathrm{KCl} 3.4 \mathrm{mM}, \mathrm{CaCl}_{2} 2.4 \mathrm{mM}, \mathrm{NaCl} 110.5 \mathrm{mM}, \mathrm{NaHCO}_{3}$ $25.7 \mathrm{mM}$, and dextrose $5.6 \mathrm{mM}$ ). The mucosa, including epithelium, was removed. Twenty-two tracheas were used on the same day of animals' death, 20 after 24-h and 8 after 48 -h storage in aerated $\left(95 \% \mathrm{O}_{2}, 5 \% \mathrm{CO}_{2}\right)$ and chilled $\left(4^{\circ} \mathrm{C}\right)$ PSS.

\section{General procedures \\ Characterization of GLY antagonism in bovine trachealis}

Tracheal strips were mounted in 25-ml glass-jacketed tissue baths, containing aerated $\left(95 \% \mathrm{O}_{2}\right.$ and $\left.5 \% \mathrm{CO}_{2}\right)$ and warm $\left(37{ }^{\circ} \mathrm{C}\right)$ PSS. Strips were treated with propranolol $10^{-6} \mathrm{M}$ and hexamethonium $10^{-5} \mathrm{M}$ to prevent $\beta$-adrenergic and nicotinic receptor activation. The strips were suspended between 2 rectangular $(1 \times 4 \mathrm{~cm})$ platinum electrodes. The lower muscle end was tied to a stationary hook and the upper to a calibrated force transducer (MODEL FT03, Grass Medical Instruments, Fullerton, CA) mounted on a micromanipulator. Forces were continuously recorded using a multichannel thermal array recorder (Gould model TA, 4000, Valley View, $\mathrm{OH}$ ) and an Arduino Due microcontroller board USB-connected to a laptop. Strips were equilibrated for $2 \mathrm{~h}$ while electrical field stimulation $(15 \mathrm{~V}, 25 \mathrm{~Hz}, 0.5 \mathrm{~ms})$ was delivered by a direct current amplifier (Mayo Clinic, Section of Engineering, Rochester, $\mathrm{MN}$ ) triggered by a stimulator (S44, Grass Medical Instruments, Quincy, MA) every $5 \mathrm{~min}$ for $30 \mathrm{~s}$. The muscles were stretched between stimulations to the length at which they produced their maximal and consistent force. This was the reference length $\left(\mathrm{L}_{\mathrm{ref}}\right)$ [13] which was not altered during each experiment. In 48 muscle strips from 6 animals, frequency response curves (from 0.06 to $64 \mathrm{~Hz}$, every $5 \mathrm{~min}$, in random order) to electrical field stimulation $(15 \mathrm{~V}, 0.5 \mathrm{~ms}, 30 \mathrm{~s})$ where first obtained. After this control assessment, muscles where first washed, then one muscle from each animal was used as control, while other 7 strips were incubated with a single dose of GLY $\left(10^{-9}-10^{-6} \mathrm{M}\right.$, halfLog increments) for $45 \mathrm{~min}$. A second frequency response curve was then obtained. In 56 muscle strips from 7 animals, dose-response curves to exogenous ACh $\left(10^{-9}-10^{-4} \mathrm{M}\right.$, cumulative half-Log increments) was first obtained. After this control assessment, muscles were washed until their resting tension was achieved. Then one strip from each animal was used as control, while other 7 strips were incubated with a single dose of GLY $\left(10^{-9}-10^{-6} \mathrm{M}\right.$, half-Log increments) for $45 \mathrm{~min}$. A second ACh dose-response curve was then obtained $\left(10^{-9}-10^{-1} \mathrm{M}\right.$, cumulative half-Log increments). At the end of each study, muscles were blotted dry and weighed. 


\section{$\left.{ }^{3} \mathrm{H}\right]-\mathrm{ACh}$-release and contractile response induced by electrical stimulation}

Two trachealis strips from each animal were suspended in 2-mL water-jacketed tissue baths containing aerated $\left(95 \% \mathrm{O}_{2}\right.$ and $\left.5 \% \mathrm{CO}_{2}\right)$ and warm $\left(37{ }^{\circ} \mathrm{C}\right)$ PSS. The muscle ends were tied to two different platinum wire electrodes connected to a micromanipulator and a force transducer (LC 4001, G0120, Litra Co, Japan), respectively. Both muscles were superfused $(1 \mathrm{~mL} / \mathrm{min})$ with PSS using a calibrated roller pump (Gilson ${ }^{\circ}$ Miniplus 3, Villiers Le Bel, France). Choline $10^{-6} \mathrm{M}$ and indomethacin $10^{-5} \mathrm{M}$ were added to reduce $\left[{ }^{3} \mathrm{H}\right]$-choline deposition on bath walls and plastic tubes and block prostaglandin synthesis, respectively. Isometric forces were continuously and simultaneously recorded (Linseis L 250 E recorder, Selby, Germany). The strips were electrically-contracted ( $25 \mathrm{~V}, 25 \mathrm{~Hz}, 0.5 \mathrm{~ms})$ every $5 \mathrm{~min}$ for $30 \mathrm{~s}$. The electrical stimuli were provided by a stimulator (S44, Grass Medical Instruments, Quincy, MA). Between stimulations, strips were stretched to $L_{\text {ref }}$ [13]. $\mathrm{L}_{\text {ref }}$ was not altered during the studies. The muscles were then superfused $(2 \mathrm{~mL} / \mathrm{min})$ with aerated warm PSS containing $1.4 \mu \mathrm{Ci} / \mathrm{mL}\left[{ }^{3} \mathrm{H}\right]$-choline (specific activity $78.3 \mathrm{Ci} / \mathrm{mM})$. During equilibration with $\left[{ }^{3} \mathrm{H}\right]$-choline both muscles were continuously electrically-stimulated $(25 \mathrm{~V}, 25 \mathrm{~Hz}, 0.5 \mathrm{~ms})$ for $30 \mathrm{~min}$ to enhance neuronal uptake of $\left[{ }^{3} \mathrm{H}\right]$-choline. Then muscles were washed $(20 \mathrm{~mL} / \mathrm{min})$ for 90 - $\mathrm{min}$ with aerated PSS added with hemicholinum-3 $10^{-5} \mathrm{M}$ to block neuronal re-uptake of $\left[{ }^{3} \mathrm{H}\right]$-choline. The PSS flow was then reduced to $1 \mathrm{~mL} /$ min and collections of superfusates were begun. This time is referred to as time zero $\left(t_{0}\right)$; $t_{n}$ indicates minutes after $t_{0}$. Superfusates were collected separately but simultaneously from both muscles for 3 min periods in vials containing $14 \mathrm{~mL}$ of liquid scintillation cocktail (Ultima Gold $^{\mathrm{Tw}}$, Perkin Elmer, Waltham, MA). Collections were interrupted twice for $10 \mathrm{~min}$ allowing the incubation with test compounds. At the end of the studies muscles were blotted dry and weighed. Each vial was assayed for radioactivity by liquid scintillation counting (LS 6500 multipurpose scintillation counter, Beckman Instruments, Fullerton CA) three times for $5 \mathrm{~min}$ and the average used for statistical analysis. Scintillation counts per minute were divided for the counting efficiency calculated from a quench curve, and disintegrations per minute were obtained. Disintegrations per stimulus were then determined from the areas bound by spontaneous and electrically induced $\left[{ }^{3} \mathrm{H}\right]$-ACh-release.

\section{Experimental protocol}

Effects of GLY, IND, or both on electrically-induced contractile response and $\left[^{3} \mathrm{H}\right]$-ACh-release (Fig. 1)

One muscle from each animal was used as control and received no study drugs. For studies with GLY alone,

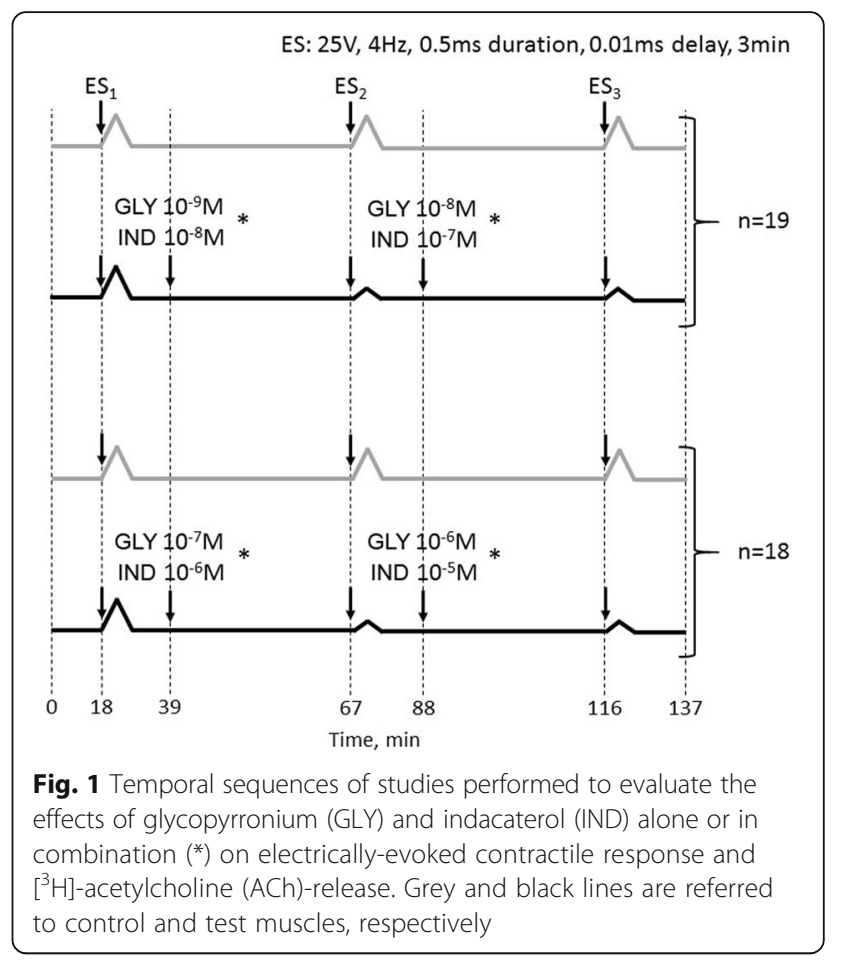

strips were pre-treated with propranolol $10^{-6} \mathrm{M}$ to prevent $\beta$-adrenergic activation. After control measurements of electrically-induced $(25 \mathrm{~V}, 4 \mathrm{~Hz}, 0.5 \mathrm{~ms}$, $3 \mathrm{~min}$ ) contractile response and $\left[{ }^{3} \mathrm{H}\right]-\mathrm{ACh}$-release at $t_{18}$, test muscles were incubated at $t_{39}$ with study drugs (GLY $10^{-9} \mathrm{M}, n=7$ or $10^{-7} \mathrm{M}, n=6$ ), or (IND $10^{-8} \mathrm{M}$, $n=6$ or $\left.10^{-6} \mathrm{M}, n=6\right)$ or (GLY $10^{-9} \mathrm{M}+$ IND $10^{-8} \mathrm{M}$, $n=6)$ or (GLY $10^{-7} \mathrm{M}+$ IND $\left.10^{-6} \mathrm{M}, n=6\right)$ and a second electrical stimulation applied at $\mathrm{t}_{67}$. Test muscles were then incubated at $\mathrm{t}_{88}$ with study drugs $\left(\mathrm{GLY} 10^{-8} \mathrm{M}\right.$, $n=7$ or $10^{-6} \mathrm{M}, n=6$ ) or (IND $10^{-7} \mathrm{M}, n=6$ or $10^{-5} \mathrm{M}$, $n=6)$ or (GLY $\left.10^{-8} \mathrm{M}+\mathrm{IND} 10^{-7} \mathrm{M}, n=6\right)$, or (GLY $\left.10^{-6} \mathrm{M}+\mathrm{IND} 10^{-5} \mathrm{M}, n=6\right)$ and a third electrical stimulation applied at $t_{116}$. At $t_{137}$ superfusate collections were stopped.

\section{Data analysis}

All contractile responses were determined as peak force minus basal tone measured at $t_{0}$. The percent changes of $\left[{ }^{3} \mathrm{H}\right]$-ACh-release and force at each $n$ stimulation was calculated as $\left[\left(\mathrm{A}_{\mathrm{n} \text { drug }} / \mathrm{A}_{1 \text { drug }}\right) /\left(\mathrm{A}_{\mathrm{n} \text { control }} / \mathrm{A}_{1}\right.\right.$ control $\left.)-1\right]$ - 100 and $\left[\left(\mathrm{F}_{\mathrm{n}}\right.\right.$ drug $/ \mathrm{F}_{1}$ drug $) /\left(\mathrm{F}_{\mathrm{n}}\right.$ control $/ \mathrm{F}_{1}$ control $\left.)-1\right]$ • 100. $A_{1}, A_{n}$ are the areas, expressed as disintegrations per stimulus, between $\left[{ }^{3} \mathrm{H}\right]$-ACh-released upon electrical stimulation and spontaneous $\left[{ }^{3} \mathrm{H}\right]$-ACh-release. $F_{1}, F_{n}$ are the corresponding forces (Fig. 2). The Bliss' equation for drug independence $[14,15]$ was used to evaluate the difference between the expected effects based on GLY and IND when given separately and the observed effects when given in combination. 

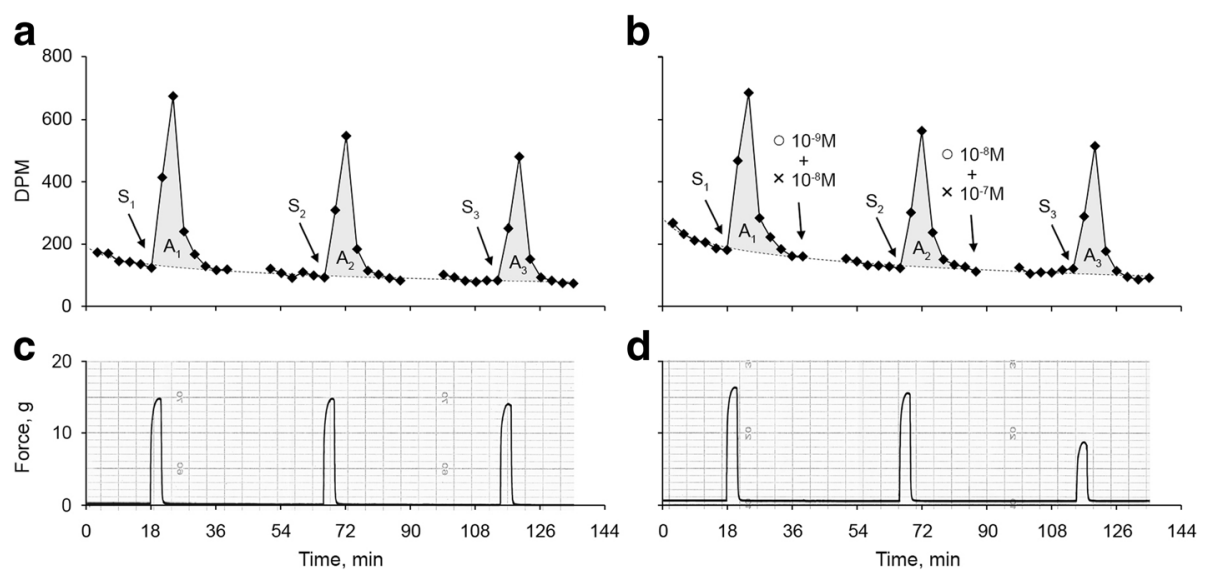

Fig. 2 Example of $\left[{ }^{3} \mathrm{H}\right]$-ACh-release (a and $\mathbf{b}$ panels) and isometric force (c and $\mathbf{d}$ panels) in response to electrical stimulation in control (a and c panels) and test (b and $\mathbf{d}$ panels) bovine trachealis. DPM are disintegrations per min. $\mathrm{S}_{1}, \mathrm{~S}_{2}$, and $\mathrm{S}_{3}$ represent first, second, and third electrical stimulation, respectively. Dashed lines represent the extrapolated spontaneous $\left[{ }^{3} \mathrm{H}\right]$-ACh-release. The grey areas $\left(A_{1}, A_{2}\right.$, and $\left.A_{3}\right)$ are the $\left[^{3} H\right]$ - $A C h-r e l e a s e$ induced by the corresponding stimulations. The electrically-induced $\left[{ }^{3} \mathrm{H}\right]$-ACh-release decrease after each stimulation $\left(A_{1}>A_{2}>A_{3}\right)$ suggesting pre-junctional neuronal depletion of $\left.{ }^{3} \mathrm{H}\right]-\mathrm{ACh}$. represent radioactivity measurements of superfusate by liquid scintillation counting. Combination of $\mathrm{GLY}(\mathrm{O})$ and IND $(X)$ inhibited the electrically-induced contractile response without altering the $\left.{ }^{3} \mathrm{H}\right]$-ACh-release

For statistical analysis, t-test for paired data and analysis of variance for repeated or independent measurements with Newmann-Keuls post-hoc test were used when appropriate. Data were analyzed and graphed using Statistica 6.0 (StatSoft, Inc., Tulsa, OK) and GraphPad Prism 6.01 (GraphPad Software, Inc., La Jolla, CA) software, respectively. $P<0.05$ was considered to be statistically significant. Data are reported as means \pm SD.

\section{Drugs}

Indomethacin, dl-propranolol hydrochloride, hemicholinium3 bromide, choline chloride, were purchased from Sigma Chemical (Milan, Italy). Methyl $\left[{ }^{3} \mathrm{H}\right]$-choline was obtained from $\mathrm{NEN}^{\mathrm{m}}$ Life Science Products, Inc. (Boston, MA), and scintillation cocktail Ultima Gold ${ }^{\mathrm{Tm}}$ from Perkin Elmer (Waltham, MA). GLY and IND were provided by Novartis Pharma (Basel, $\mathrm{CH}$ ). Indomethacin was dissolved in absolute ethanol and IND in dimethyl sulfoxide; all other compounds were dissolved in distilled water. Fresh solutions were prepared weekly and stored at $4{ }^{\circ} \mathrm{C}$ to be used within 7 days.

\section{Results}

One hundred and seventy-eight muscle strips from 50 animals were used, their physical and functional characteristics at baseline are reported in Additional file 1: Table S1. Neither GLY nor IND altered the muscle resting tone. GLY caused significant rightward shifts of response curves to both frequency and exogenous ACh at concentration larger or equal to $10^{-8} \mathrm{M}(p<0.001$, Fig. 3). Schild regression analysis yielded a $\mathrm{pA}_{2}$ of $8.68 \pm 0.21$ and a slope of $-1.06 \pm 0.07$ which was not significantly different from unity $(p=0.267)$ suggesting

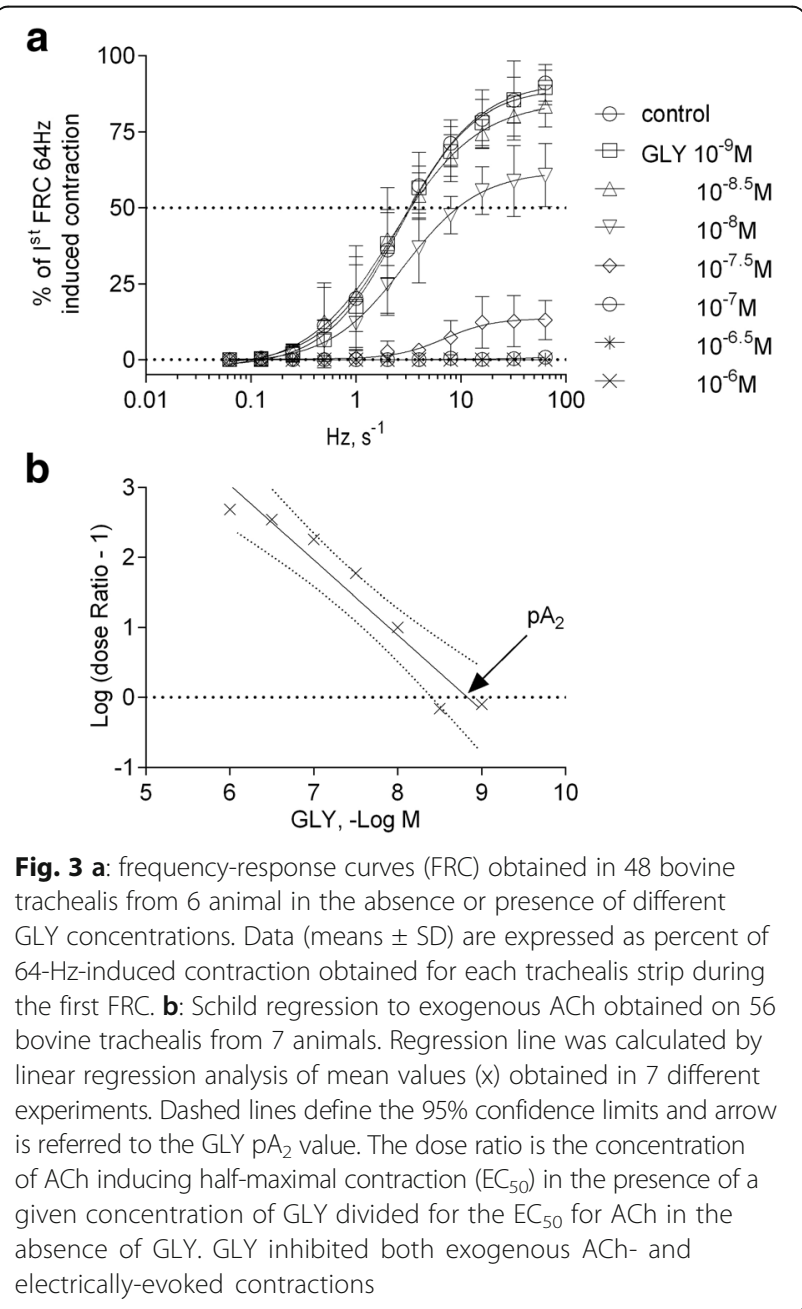


competitive antagonism [16] (Fig. 3). The $\left[{ }^{3} \mathrm{H}\right]$-ACh-release consistently decreased in all muscle with time (Fig. 2) due to progressive depletion of radiolabeled $\mathrm{ACh}$ and inhibition of neural choline uptake induced by hemicholinium-3 [3, 5-8, 17-19].

\section{Effects of GLY on electrically-evoked contractile response} and $\left[{ }^{3} \mathrm{H}\right]-\mathrm{ACh}$-release (Fig. 4)

GLY had no significant $(p>0.726)$ effect on either contractile response or $\left[{ }^{3} \mathrm{H}\right]$-ACh-release at $10^{-9} \mathrm{M}$ $\left(-2 \pm 3 \%\right.$ and $-3 \pm 5 \%$, respectively). At $10^{-8} \mathrm{M}$, GLY significantly reduced the contractile response $(-19 \pm 6 \%$, $p=0.010)$ without significantly altering $\left[{ }^{3} \mathrm{H}\right]$-ACh-release $(6 \pm 11 \%, p=0.604)$. At $10^{-7} \mathrm{M}$ and $10^{-6} \mathrm{M}$ the contractile responses were significantly reduced $(-97 \pm 3 \%, p<0.001$ and $-99 \pm 1 \%, p<0.001$, respectively). These reductions were associated with significant increments of $\left[{ }^{3} \mathrm{H}\right]$-ACh-release at $10^{-7} \mathrm{M}$ and $10^{-6} \mathrm{M}(27 \pm 19 \%$, $p<0.001$ and $20 \pm 8 \%, p=0.004$, respectively).

\section{Effects of IND on electrically-evoked contractile response and $\left[{ }^{3} \mathrm{H}\right]$-ACh-release (Fig. 4)}

IND had no significant $(p>0.607)$ effects on either contractile response or $\left[{ }^{3} \mathrm{H}\right]-\mathrm{ACh}$-release at $10^{-8} \mathrm{M}$

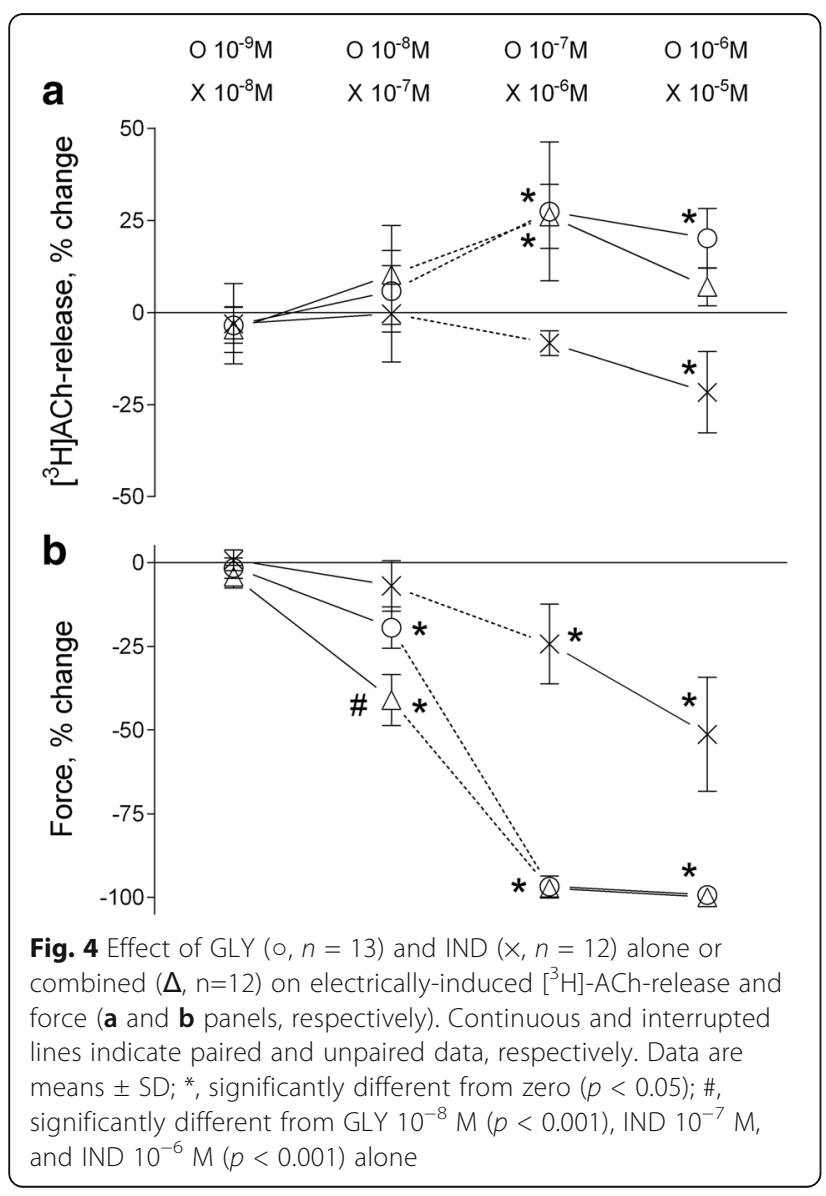

(1 $\pm 3 \%$ and $-2 \pm 6 \%$, respectively) and $10^{-7} \mathrm{M}$ $\left(-7 \pm 7 \%\right.$ and $0 \pm 13 \%$, respectively). At $10^{-6} \mathrm{M}$, IND significantly reduced the contractile response $(-24 \pm 12 \%, p=0.002)$ without significantly altering $\left[{ }^{3} \mathrm{H}\right]$-ACh-release $(-8 \pm 3 \%, p=0.396)$. At $10^{-5} \mathrm{M}$ the contractile response was reduced $(-51 \pm 17 \%$, $p<0.001)$ and this was associated with a decrease of $\left[{ }^{3} \mathrm{H}\right]$-ACh-release $(-22 \pm 11 \%, p=0.004)$.

Effects of combined GLY and IND on electrically-evoked contractile response and $\left[{ }^{3} \mathrm{H}\right]-\mathrm{ACh}$-release (Fig. 4)

Co-incubation with GLY $10^{-9} \mathrm{M}$ and IND $10^{-8} \mathrm{M}$ had no significant $(p>0.970)$ effects on either contractile response or $\left[{ }^{3} \mathrm{H}\right]$-ACh-release $(-4 \pm 3 \%$ and $-5 \pm 6 \%$, respectively). Co-incubation with GLY $10^{-8} \mathrm{M}$ and IND $10^{-7} \mathrm{M}$ inhibited the contractile response $(-41 \pm 8 \%$, $p<0.001)$ significantly more than GLY $10^{-8} \mathrm{M}$ alone $(-19 \pm 6 \%, p<0.001)$, or IND $10^{-7} \mathrm{M}$ alone $(-7 \pm 7 \%$, $p<0.001)$, or IND $10^{-6} \mathrm{M}$ alone $(-24 \pm 12 \%$, $p<0.001)$ without significantly altering $\left[{ }^{3} \mathrm{H}\right]-\mathrm{ACh}-\mathrm{re}-$ lease $(10 \pm 13 \%, p=0.368)$. With GLY $10^{-7} \mathrm{M}$ and IND $10^{-6} \mathrm{M}$ neither contractile response nor $\left[{ }^{3} \mathrm{H}\right]-\mathrm{ACh}-\mathrm{re}-$ lease significantly differed from those with GLY $10^{-7} \mathrm{M}$ alone $(-97 \pm 3 \%$ vs $-97 \pm 3 \%, p=0.899$ and $26 \pm 9 \%$ vs $27 \pm 19 \%, p=0.775$, respectively). With GLY $10^{-6} \mathrm{M}$ and IND $10^{-5} \mathrm{M}$ the contractile responses were not significantly different from that with GLY $10^{-6} \mathrm{M}$ alone $(-100 \pm 0.1 \%$ vs $-99 \pm 1 \% p=0.893)$ while the increase of $\left[{ }^{3} \mathrm{H}\right]$-ACh-release was significantly reduced $(7 \pm 5 \%$ vs $20 \pm 8 \%, p=0.019$ ).

\section{Comparison between expected and observed effects of GLY and IND combination}

For $\left[{ }^{3} \mathrm{H}\right]$-ACh-release none of the observed effects of combination was significantly different from those expected based on their effects when given separately $(p>0.622)$, suggesting additive effects. For contractile response, the observed effect with the combination of GLY $10^{-8} \mathrm{M}$ and IND $10^{-7} \mathrm{M}$ was significantly greater than the expected $(41 \pm 8 \%$ vs. $28 \pm 10 \% p=0.002)$, suggesting a more than additive effect.

\section{Discussion}

The main findings of the present study are that 1) on equimolar basis GLY had a significantly larger inhibitory effect on electrically- induced contraction of airway smooth muscle than IND, even if it caused an increase in ACh-release, 2) the combination of GLY $10^{-8} \mathrm{M}$ with IND $10^{-7} \mathrm{M}$ had a more than additive effect in inhibiting the contractile response, without significantly altering $\left[{ }^{3} \mathrm{H}\right]$-ACh-release, and 3) adding GLY to IND had a greater effect than increasing the concentration of IND alone. 
Comments on methodology and study limitations

ACh-release was evaluated from the outflow of $\left[{ }^{3} \mathrm{H}\right]$. The validity of this method for measuring $\left[{ }^{3} \mathrm{H}\right]-\mathrm{ACh}$ has been demonstrated by Kilbinger et al. in 1991 [3]. The strength of this method is that it does not require cholinesterase inhibitors, thus avoiding unphysiological high concentrations of $\mathrm{ACh}$ resulting in M-receptor autoinhibition. A potential problem of this technique is that the release of $\left[{ }^{3} \mathrm{H}\right]$-ACh may not reflect accurately the release of endogenous ACh [18], but this has not been confirmed [19]. In order to measure quantitatively the electrically induced ACh-release, neuronal re-uptake of $\left[{ }^{3} \mathrm{H}\right]$-choline was blocked by hemicholinium-3, resulting in $\left[{ }^{3} \mathrm{H}\right]$-ACh depletion in postganglionic cholinergic nerve endings with each consecutive electric stimulation. The number of consecutive stimulations in each study was therefore limited to three. However, $\left[{ }^{3} \mathrm{H}\right]$-ACh-release is affected by the magnitude of depletion with previous stimulations. If $\left[{ }^{3} \mathrm{H}\right]-\mathrm{ACh}$-release is altered by study drugs, depletion can either be increased or reduced with the second stimulation, thus leaving less or more $\left[{ }^{3} \mathrm{H}\right]-\mathrm{ACh}$ available to be released with the third electrical stimulation. In the present study there were no significant differences in $\left[{ }^{3} \mathrm{H}\right]$-ACh-release after second stimulation between control muscles and muscles treated with either GLY $10^{-9} \mathrm{M}$, IND $10^{-8} \mathrm{M}$, IND 10 ${ }^{-6} \mathrm{M}$, or with GLY $10^{-9} \mathrm{M}$ co-incubated with IND 10 ${ }^{-8} \mathrm{M}$. With the highest GLY concentrations, the $\left[{ }^{3} \mathrm{H}\right]-$ ACh-release was greater than control, therefore there is a possibility that $\left[{ }^{3} \mathrm{H}\right]$-ACh-release after GLY $10^{-6} \mathrm{M}$ incubation might have been underestimated.

The frequency of $4 \mathrm{~Hz}$ for the assessment of electrically-induced $\left[{ }^{3} \mathrm{H}\right]$-ACh-release and contractile response was chosen from frequency-response curves, where it caused a near half-maximal contraction. The concentrations of GLY and IND used in the electricallyinduced $\left[{ }^{3} \mathrm{H}\right]$-ACh-release and contractile response experiments were chosen from the frequency- and exogenous ACh-response curves characterizing GLY antagonism and from previous data with other $\beta$ adrenoceptor agonists [8], respectively.

Electrically-induced ACh-release may be attenuated in isolated bovine trachealis by stimulation of pre-junctional $\beta_{2}$-adrenoceptor [8]. Thus, in experiments with GLY alone, propranolol was added. Activation of muscarinic receptors stimulates synthesis and release of prostaglandins, which in turn reduces ACh-release [4, 20, 21]. Thus, to avoid any confounding effect of prostaglandins, studies were done in the presence of indomethacin.

The present study was done using bovine trachealis. Therefore, any extrapolation of our data to human bronchi either in healthy subjects or in patients having COPD, with different $\beta_{2}$-adrenoceptor and $M$-receptor density [22], should be draw cautiously. The choice of this tissue was based on the sufficient availability to conduct the large number of experiments necessary for the study and because muscarinic autoregulation [6] is present in this tissue similar to human airways $[1,2,5]$.

Isometric contraction does not represent what happens in vivo, where airway smooth muscle contraction occurs under auxotonic conditions. However, this does not invalidate conclusions regarding interactions between drugs acting on different receptors.

\section{Comments on results}

Long-acting $\beta_{2}$-adrenoceptor agonists and cholinergic M-receptor antagonists are recommended by expert committees [23] and guidelines [24, 25] as the cornerstone treatment for COPD. No specific recommendations are given on the strategy to optimize the use of these drugs. One option is starting treatment with either one of them and, if not sufficient to control symptoms, increasing the dosage of the same drug or adding a second one; an alternative option is starting with lowdosage combination treatment. The M-receptor antagonist ipratropium caused a bronchodilator effect that was maximal in patients with bronchitis but not in those with bronchial asthma [26]. Based on this finding, it has long been thought that cholinergic tone and the amplifying effect of airway wall thickening are the main mechanisms for airway narrowing in COPD [26-29]. Because no difference was observed between ipratropium and a combination of fenoterol plus theophylline, the choice between $\beta_{2}$-adrenoceptor agonists and $\mathrm{M}$-receptor antagonists as monotherapy for COPD has been considered as a matter of side effects more than efficacy. If these data from isolated bovine airways can be extrapolated to human airways, then the results would suggest that muscarinic antagonists might represent the treatment of choice and the better strategy for monotherapy in COPD.

The superiority of GLY over IND in attenuating airway smooth muscle contraction might appear surprising owing to the expected opposing effects of these drugs on ACh-release from pre-junctional post-ganglionic nerves. As other available anti-muscarinic drugs, GLY is not selective for $\mathrm{M}_{3}$-receptor [30,31], but it increases $\mathrm{ACh}$ release by antagonizing also pre-junctional $\mathrm{M}_{2}$ and/or $M_{4}$ receptors $[3,5,6]$. By contrast, $\beta_{2}$-adrenoceptor agonists may reduce $\mathrm{ACh}$-release by opening pre-junctional $\mathrm{Ca}^{2+}$-dependent $\mathrm{K}^{+}$channels $[8,32]$. In the present study, at concentration of GLY less than $10^{-7} \mathrm{M}$, electrically-induced ACh-release remained unaltered, whereas at concentrations of $10^{-7} \mathrm{M}$ and $10^{-6} \mathrm{M}$ the ACh-release was increased. This difference in response might be due to blocking ganglionic $\mathrm{M}_{1}$-receptors at low concentrations offsetting the effect on post-ganglionic $\mathrm{M}_{2}$-receptor at low but not high concentrations [33-35]. 
The increments of ACh-release with GLY or GLY + IND were on average between 20 and $27 \%$. Based on a previous study using opioid agonists [7] and frequency-response curves (Additional file 1: Figure S1), we estimated that these changes would have resulted in changes of force between 8 and 10\% in the absence of drugs acting at post-junctional level. These changes, however, cannot be quantitatively extrapolated to in vivo conditions for a series of reasons. First, the relationship between AChrelease and force is not linear and the frequency of vagal firing may be variably affected by different stimuli [36]. Second, changes in airway smooth muscle force translate into changes of linear length depending on opposing loads [27]. Finally, changes in linear length translate into changes in airway caliber depending on airway geometry [29]. It can be speculated that changes in force may translate into greater changes of airway caliber in COPD than healthy subjects because of the increased thickness of airway walls and the loss of lung elastic recoil [27-29].

Interestingly, the contractile responses were abolished by $10^{-7} \mathrm{M}$ and $10^{-6} \mathrm{M}$ concentrations of GLY, despite an increase of ACh-release. Presumably, complete blockade of post-junctional $\mathrm{M}_{3}$-receptor prevented a contractile response to the increased ACh-release. This is consistent with the absence of contractile non-cholinergic stimuli in bovine trachealis [6]. Conversely, at $10^{-5} \mathrm{M}$ IND reduced ACh-release and, importantly, the net inhibitory effects on contractile responses were less than with GLY lower concentrations.

A major objective of the present study was to investigate whether the GLY-IND combination may have additive or more-than additive effects in reducing airway smooth muscle contraction and ACh-release. The combination of GLY $10^{-8} \mathrm{M}$ with IND $10^{-7} \mathrm{M}$ attenuated contractions more than GLY $10^{-8} \mathrm{M}$, or IND $10^{-7} \mathrm{M}$ given separately, and the expected based on Bliss independent criterion [14, 15]. This more than additive effect in conjunction with the insignificant effects of IND $10^{-7} \mathrm{M}$ alone on ACh-release suggest a synergistic effect at post-junctional level, rather than a functional antagonism at pre-junctional level.

$\mathrm{M}_{2}$-receptors are expressed not only pre-junctionally on nerves but also post-junctionally on airway smooth muscle cell membrane [37, 38]. Inhibition of postjunctional $\mathrm{M}_{2}$ receptors by muscarinic antagonist inhibits the receptor-coupled $G_{i} \alpha$ subunit, thus favoring the adenylyl cyclase activity, the cAMP accumulation, and thereby the relaxant effect of $\beta_{2}$-adrenoceptor agonists [39, 40]. Therefore, non-selective muscarinic antagonists may increase the relaxing effects of $\beta_{2^{-}}$ adrenoceptor agonists. Indeed, in human bronchi a greater cAMP concentration has been observed with a GLY-IND combination than with IND alone [11].
An important finding of this study is that adding a low concentration $\left(10^{-8} \mathrm{M}\right)$ of GLY to IND $10^{-7} \mathrm{M}$ had an inhibitory effect on airway smooth muscle contraction that was superior to increasing IND concentration by 10 times and not inferior to increasing it by 100 times.

\section{Conclusions}

In isolated bovine trachealis, at equimolar concentration, the muscarinic antagonist GLY has a significant larger inhibitory effect on airway smooth muscle contraction than IND. Importantly, a combination of GLY with IND at submaximal concentrations can provide a significantly larger inhibition of contractile response than either drug alone without altering ACh-release, suggesting a synergistic post-junctional effect. Collectively, this study suggests that GLY may be the first-choice for monotherapy and low-dosage combination of GLY and IND may be preferable than increasing IND alone.

\section{Additional file}

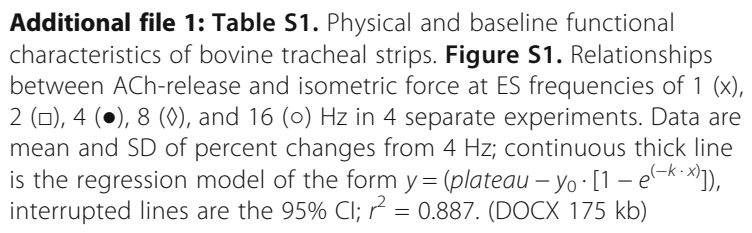

\section{Abbreviations}

A: Area; ACh: Acetylcholine; COPD: Chronic obstructive pulmonary disease; F: Force; GLY: Glycopyrronium; IND: Indacaterol; M: Muscarinic; PSS: Physiologic salt solution

\section{Acknowledgements}

Not applicable.

\section{Funding}

The study was supported by a Grant from Novartis Pharma (Basil, CH). M.B, and V.B. are employees of the University of Genoa and G.B. of the IRCCS San Martino Hospital. None of them received external funding.

\section{Availability of data and materials}

The datasets used and analyzed during this study are available from the corresponding author on reasonable request and with Novartis permission.

\section{Authors' contributions}

MB designed the study, performed the experiments, analyzed data, interpreted the experimental results, prepare figures, drafted, edited and revised the manuscript. GB interpreted the experimental results, edited and revised manuscript. VB designed the study, analyzed data, interpreted the experimental results, drafted, edited and revised the manuscript. All authors read and approved the final manuscript.

\section{Ethics approval}

Bovine tracheas were obtained, after permissions, from BLM Carni S.r.l., via Brughiera 10, 16030 Tribogna, Genoa and Fasce Gian Mario Ditta Individuale, via Recroso 241/bis, 16024 Lumarzo, Genoa. Ethical approval was not required because none of the authors was involved in the care or killing of the animals. Bovine care and slaughtering procedures were done according to the Italian law.

Consent for publication

Not applicable. 


\section{Competing interests}

M.B. and G.B. have no competing interests to declare. V.B. has acted in a consultancy capacity and given lectures and has received fees from Boehringer Ingelheim, Dompé, GSK, Menarini, Novartis, AstraZeneca, Almirall. V.B. institution has received research support from Novartis and Chiesi.

\section{Publisher's Note}

Springer Nature remains neutral with regard to jurisdictional claims in published maps and institutional affiliations.

\section{Author details}

'Dipartimento di Medicina Interna e Specialità Mediche, Università di Genova, Viale Benedetto XV 6, 16132 Genoa, Italy. ${ }^{2}$ Ospedale Policlinico San Martino, Largo R. Benzi 10, 16132 Genoa, Italy.

Received: 28 February 2017 Accepted: 19 July 2017

Published online: 28 July 2017

\section{References}

1. Patel HJ, Barnes PJ, Takahashi T, Tadjkarimi S, Yacoub MH, Belvisi MG. Evidence for pre-junctional muscarinic autoreceptors in human and guinea pig trachea. Am J Respir Crit Care Med. 1995:152(3):872-8.

2. Ten Berge RE, Zaagsma J, Roffel AF. Muscarinic inhibitory autoreceptors in different generations of human airways. Am J Respir Crit Care Med. 1996;154(1):43-9.

3. Kilbinger $H$, Schneider $R$, Siefken $H$, Wolf D, D'Agostino $G$. Characterization of prejunctional muscarinic autoreceptors in the guinea-pig trachea. $\mathrm{Br}$ J Pharmacol. 1991;103(3):1757-63.

4. Ito Y, Yoshitomi T. Autoregulation of acetylcholine release from vagus nerve terminals through activation of muscarinic receptors in the dog trachea. Br J Pharmacol. 1988:93(3):636-46.

5. Wessler I, Bender H, Härle P, Höhle KD, Kirdorf G, Klapproth $H$, et al. Release of $[3 \mathrm{H}]$ acetylcholine in human isolated bronchi. Effect of indomethacin on muscarinic autoinhibition. Am J Respir Crit Care Med. 1995;151(4):1040-6.

6. Baroffio M, Crimi E, Brichetto L, Zappi L, Rehder K, Brusasco V. Pre-junctional muscarinic autoreceptors in bovine airways. Respir Physiol Neurobiol. 2012:180(1):45-51. doi:10.1016/j.resp.2011.10.007.

7. Baroffio M, Crimi E, Rehder K, Brusasco V. Effects of $\mathrm{K}$ - and $\mu$-opioid agonists on cholinergic neurotransmission and contraction in isolated bovine trachealis. Respir Physiol Neurobiol. 2013;185(2):281-6. doi:10.1016/j.resp.2012.10.001.

8. Brichetto L, Song P, Crimi E, Rehder K, Brusasco V. Modulation of cholinergic responsiveness through the [beta]-adrenoceptor signal transmission pathway in bovine trachealis. J Appl Physiol. 2003;95(2):735-41.

9. Barisione G, Baroffio M, Crimi E, Brusasco V. Beta-adrenergic agonists. Pharmaceuticals. 2010;3(4):1016-44

10. Belmonte KE. Cholinergic pathways in the lungs and anticholinergic therapy for chronic obstructive pulmonary disease. Proc Am Thorac Soc. 2005:2(4):297-304

11. Cazzola M, Calzetta L, Puxeddu E, Ora J, Facciolo F, Rogliani P, Matera MG. Pharmacological characterisation of the interaction between glycopyrronium bromide and indacaterol fumarate in human isolated bronchi, small airways and bronchial epithelial cells. Respir Res. 2016;17:70. doi:10.1186/s12931-016-0386-8.

12. Barilan A, Nachman-Rubinstein R, Oron Y, Geyer O. Muscarinic blockers potentiate beta-adrenergic relaxation of bovine iris sphincter. Graefes Arch Clin Exp Ophthalmol. 2003:241(3):226-31.

13. Bai TR, Bates JH, Brusasco V, Camoretti-Mercado B, Chitano P, Deng LH, et al. On the terminology for describing the length-force relationship and its changes in airway smooth muscle. J Appl Physiol. 2004;97(6):2029-34.

14. Bliss Cl. The toxicity of poisons applied jointly. Ann Appl Biol. 1939;26(3):585-615.

15. Goldoni M, Johansson C. A mathematical approach to study combined effects of toxicants in vitro: evaluation of the bliss independence criterion and the Loewe additivity model. Toxicol in Vitro. 2007;21(5):759-69.

16. Arunlakshana $\mathrm{O}$, Schild $\mathrm{HO}$. Some quantitative uses of drug antagonists. Br J Pharmacol Chemother. 1959;14(1):48-58.

17. Patel HJ, Giembycz MA, Spicuzza L, Barnes PJ, Belvisi MG. Naloxone-insensitive inhibition of acetylcholine release from parasympathetic nerves innervating guinea-pig trachea by the novel opioid, nociceptin. Br J Pharmacol. 1997:120(5):735-6.

18. Beani L, Bianchi C, Siniscalchi A, Sivilotti L, Tanganelli S, Veratti E. Different approaches to study acetylcholine release: endogenous ACh versus tritium efflux. Naunyn Schmiedeberg's Arch Pharmacol. 1984;328(2):119-26.
19. Wessler I. Acetylcholine at motor nerves: storage, release, and presynaptic modulation by autoreceptors and adrenoceptors. Int Rev Neurobiol. 1992;34:283-384

20. Inoue T, Ito Y, Takeda K. Prostaglandin-induced inhibition of acetylcholine release from neuronal elements of dog tracheal tissue. J Physiol. 1984 349:553-70.

21. Ito $Y$, Tajima K. Actions of indomethacin and prostaglandins on neuroeffector transmission in the dog trachea. J Physiol. 1981;319:379-92.

22. Ikeda T, Anisuzzaman AS, Yoshiki H, Sasaki M, Koshiji T, Uwada J, et al. Regional quantification of muscarinic acetylcholine receptors and $\beta$ adrenoceptors in human airways. Br J Pharmacol. 2012;166(6):1804-14. doi:10.1111/j.1476-5381.2012.01881.x

23. From the global strategy for the diagnosis, management and prevention of COPD, global initiative for chronic obstructive lung disease (GOLD) 2017. http://goldcopd.org/gold-2017-global-strategy-diagnosis-managementprevention-copd.

24. National Institute for Health and Care Excellence. Chronic obstructive pulmonary disease in in over 16s: diagnosis and management. Clinical Guideline. http://nice.org.uk/guidance. Accessed 23 June 2010.

25. O'Donnell DE, Aaron S, Bourbeau J, Hernandez P, Marciniuk DD, Balter M, et al. Canadian thoracic society recommendations for management of chronic obstructive pulmonary disease - 2007 update. Can Respir J. 2007;14(Suppl B):5B-32B.

26. Lefcoe NM, Toogood JH, Blennerhassett G, Baskerville J, Paterson NA The addition of an aerosol anticholinergic to an oral beta agonist plus theophylline in asthma and bronchitis. A double-blind single dose study. Chest. 1982;82(3):300-5.

27. Wiggs BR, Moreno R, Hogg JC, Hilliam C, Paré PD. A model of the mechanics of airway narrowing. J Appl Physiol. 1990;69(3):849-60.

28. Kuwano K, Bosken CH, Paré PD, Bai TR, Wiggs BR, Hogg JC. Small airways dimensions in asthma and in chronic obstructive pulmonary disease. Am Rev Respir Dis. 1993;148(5):1220-5.

29. Paré PD, Bai TR. Airway wall remodeling in chronic obstructive pulmonary disease. Eur Respir Rev. 1996;6(39):259-63.

30. Haddad EB, Patel H, Keeling JE, Yacoub MH, Barnes PJ, Belvisi MG. Pharmacological characterization of the muscarinic receptor antagonist, glycopyrrolate, in human and guinea-pig airways. Br J Pharmacol. 1999;127(2):413-20.

31. Alagha K, Palot A, Sofalvi T, Pahus L, Gouitaa M, Tummino C, et al. Long-acting muscarinic receptor antagonists for the treatment of chronic airway diseases. Ther Adv Chronic Dis. 2014;5(2):85-98. doi:10.1177/2040622313518227.

32. Patel HJ, Giembycz MA, Keeling JE, Barnes PJ, Belvisi MG. Inhibition of cholinergic neurotransmission in guinea pig trachea by NS1619, a putative activator of large-conductance, calcium-activated potassium channels. J Pharmacol Exp Ther. 1998;286(2):952-8.

33. Lammers JW, Minette P, McCusker M, Barnes PJ. The role of pirenzepinesensitive (M1) muscarinic receptors in vagally mediated bronchoconstriction in humans. Am Rev Respir Dis. 1989;139(2):446-9.

34. Bloom JW, Yamamura HI, Baumgartener $\mathrm{C}$, Halonen M. A muscarinic receptor with high affinity for pirenzepine mediates vagally induced bronchoconstriction. Eur J Pharmacol. 1987;133(1):21-7.

35. Barnes PJ. Muscarinic receptor subtypes in airways. Eur Respir J. 1993;6(3):328-31

36. Widdicombe JG. Action potentials in parasympathetic and sympathetic efferent fibres to the trachea and lung of dogs and cats. J Physiol. 1966; 186:56-88.

37. Mak JC, Baraniuk JN, Barnes PJ. Localization of muscarinic receptor subtype mRNAs in human lung. Am J Respir Cell Mol Biol. 1992;7(3):344-8.

38. Roffel AF, Elzinga $C R$, van Amsterdam RG, de Zeeuw RA, Zaagsma J. Muscarinic M2-receptors in bovine tracheal smooth muscle: discrepancies between binding and function. Eur J Pharmacol. 1988;153(1):73-82.

39. Ostrom RS, Ehlert FJ. M2 muscarinic receptor inhibition of agonist-induced cyclic adenosine monophosphate accumulation and relaxation in the guinea pig ileum. J Pharmacol Exp Ther. 1997;280(1):189-99.

40. Ostrom RS, Ehlert FJ. M2 muscarinic receptors inhibit forskolin- but not isoproterenol-mediated relaxation in bovine tracheal smooth muscle. J Pharmacol Exp Ther. 1998;286(1):234-42. 